\title{
MIR520C wt Allele
}

National Cancer Institute

\section{Source}

National Cancer Institute. MIR520C wt Allele. NCI Thesaurus. Code C82207.

The human MIR520C wild-type allele is located in the vicinity of $19 q 13.41$ and is approximately 86 bases in length. This allele, which encodes MIR520C pre-miRNA, plays a role in the regulation of gene expression. Alteration in the expression of this gene is associated with development of breast cancer. 